\title{
Spatial Sciences on Ice: 50 years of Australian activities on the Amery Ice Shelf, East Antarctica
}

\author{
Volker Janssen and Rachael Hurd \\ Surveying and Spatial Sciences \\ School of Geography and Environmental Studies \\ University of Tasmania \\ Private Bag 76, Hobart TAS 7001, Australia \\ Phone (03) 6226 2844, Fax (03) 62267628 \\ Volker.Janssen@utas.edu.au
}

\begin{abstract}
The Antarctic climate system involves many complex interactions between the atmosphere, oceans and ice and is sensitive to variations in these components. Ice shelves represent the ice-ocean-atmosphere interface of the Antarctic continent and are therefore very important indicators of climate change in the region. The Amery Ice Shelf is the largest ice shelf in East Antarctica and has been the focus of many scientific research projects over the past 50 years. This paper presents a history of the use of spatial science techniques from basic survey equipment to satellite systems in Australian research projects based on the Amery Ice Shelf (and surrounding glaciers) since 1955. The application of these spatial data to projects primarily based in the fields of geodesy, glaciology, climatology, and oceanography has allowed the measurement and monitoring of the physical, dynamic and environmental characteristics of this large and remote region. This new information provides scientists with a better understanding of the ice shelf-ocean-atmosphere system allowing future monitoring to observe the effects of global climate change.
\end{abstract}

KEY WORDS Spatial sciences; climate change; conventional surveying; Global Positioning System (GPS); satellite remote sensing; Amery Ice Shelf; Antarctica.

\section{Introduction}

Antarctica stores approximately $60 \%$ of the freshwater and approximately $90 \%$ of the ice on the Earth's surface (Meier 1993) and is therefore an extremely important component of the Earth's climate system. Ice in Antarctica can be classified into three types, grounded ice (ice streams and ice sheets), ice shelves and sea ice. One way of observing the effects of climate change in this region is to monitor the amount and distribution of ice in each of these categories.

Ice shelves are the floating extension of a grounded glacier or ice sheet over the ocean (Thomas 1979) (see Figure 1). They are important environmental change indicators as they are the primary means of mass loss from the continent via either iceberg calving (production of icebergs due to break-off from the ice shelf) or basal melt (melting of ice at the bottom of the ice shelf due to warmer ocean temperatures or increased pressure) and as such it is important to understand their processes and monitor changes (e.g. Jacobs et al. 1992, Williams et al. 2002). 


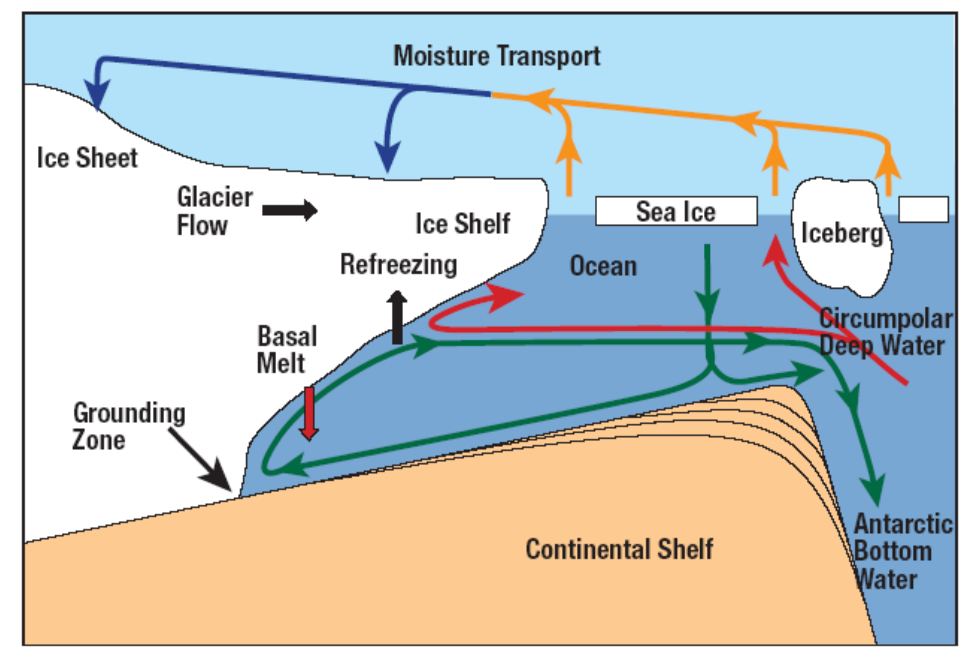

FIGURE 1. Schematic representation of an ice shelf and its interactions with the ocean and atmosphere. Source: Allison (2001).

This paper focuses on spatial science projects that were designed to understand the characteristics of the Amery Ice Shelf (AIS) and the glaciers that feed it. Geographically the AIS is located at $\left(\sim 71^{\circ} \mathrm{S}, \sim 70^{\circ} \mathrm{E}\right)$ in East Antarctica between the Australian stations of Davis and Mawson. The AIS is the outlet of the Lambert Glacier Drainage Basin (LGB) which drains continental ice from an area of more than one million square kilometres (Allison 1991) through a section of coastline that represents approximately $1.7 \%$ of the total continental circumference (Budd et al. 1967), and it is a very dynamic system. The ice in the AIS flows with velocities of up to approximately $1350 \mathrm{~m} / \mathrm{yr}$ (at the ice shelf front) (Young \& Hyland 2002) and, as it is floating, is affected by ocean tides causing continuous vertical motion at all points north of the grounding zone.

Since their foundation in 1947, the Australian National Antarctic Research Expeditions (ANARE) have played a major role in improving scientific knowledge of the Antarctic continent, and the AIS and LGB have been one of the primary areas of field research during this time. This paper outlines how Australian survey projects on the AIS have evolved from using instruments such as barometers, compasses, optical theodolites and levels in the 1960s to GPS equipment and satellite data in recent times. These projects have provided vital spatial information for scientists in many other disciplines including geodesy, glaciology, climatology, oceanography and remote sensing and allowed them to monitor and develop a better understanding of the physical and environmental characteristics of such a large, remote and climatologically sensitive region.

\section{Field surveys (1955-74)}

During this period, fieldwork was restricted by logistical and instrumental constraints and therefore mostly concentrated on the northern part of the AIS. In terms of equipment, the projects undertaken prior to the 1980s initially used compass, tape, wheels and barometers, moving on to traditional terrestrial surveying theodolites, levels and electronic distance measurement (EDM) equipment as well as aerial photography and airborne radio echo sounding. The following summarises the survey projects undertaken on the AIS during this time. 
1955-65

The Amery Ice Shelf was first sighted by air on 11 February 1931 by Sir Douglas Mawson (Corry 1986a). In January 1955 the ice shelf front was charted by ship, marking the first ANARE activity in the region (Law 1967). Following aerial photography of the Amery Ice Shelf during several seasons in the late 1950s, the first surface observations on the AIS by ANARE started in late 1962 (Law 1967) with strain measurements made during a reconnaissance survey, which also included two dog teams (Corry 1986a) (see Plate 1). The ice shelf front was again mapped by ship and an astrofix (position determination by astronomical observation) carried out to determine the rate of forward motion since a Russian expedition in 1957 (Budd et al. 1967).

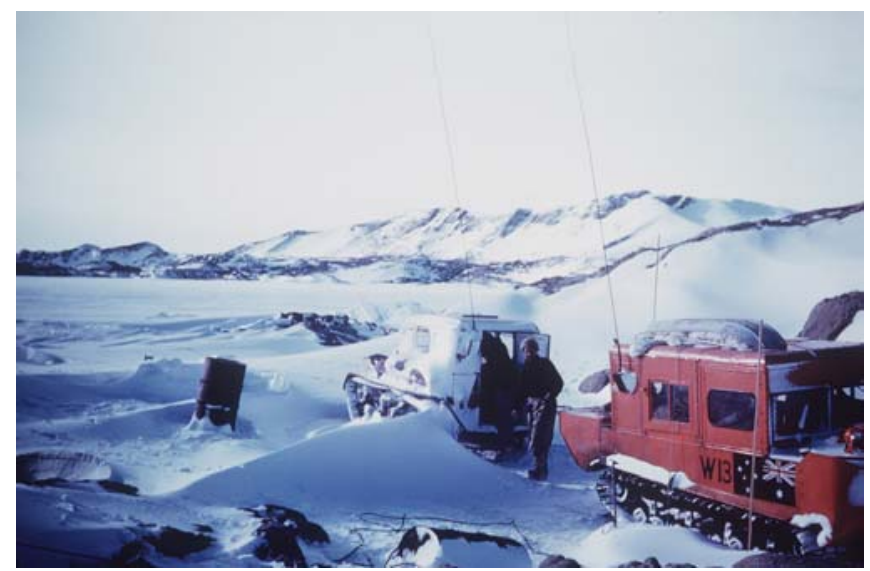

Plate 1. Snow Trac and Weasel during heavy vehicle passage to the AIS, October 1962. Photograph by Robert Nelson, Australian Government Antarctic Division (C) Commonwealth of Australia.

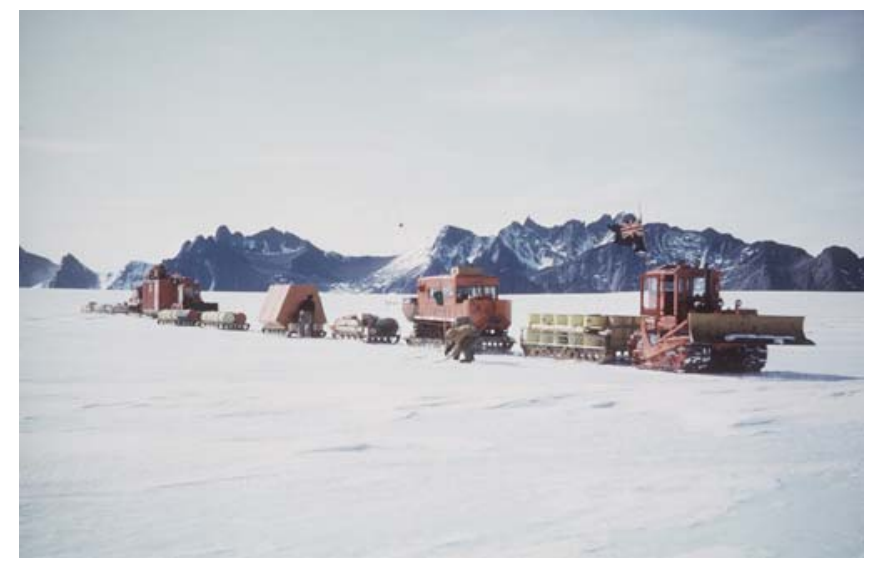

Plate 2. Tractor train hauled by a Caterpillar D4 in the Prince Charles Mountains en route to the AIS, 1964. Photograph by Bruce H. Allport, Australian Government Antarctic Division (C) Commonwealth of Australia.

In late 1963 and late 1964 the first major field-based survey program on the AIS was commenced (see Plate 2). This project was designed to collect a large amount of snow accumulation and ice velocity/strain rate data via the positioning and re-measurement of an extensive network of stakes (see Figure 2). In late 1963 two dog teams, supported by two tractor trains, placed stakes $3.2 \mathrm{~km}$ apart, in a line stretching longitudinally for over 
$200 \mathrm{~km}$ down the centre of the ice shelf (from G1 to T4) and in two lateral lines near either end of the traverse route (Corry 1986a). Strain grids were also established at three points along the central flow-line (G1, G2, G3 - see Figure 2) to measure longitudinal and transverse strain rates with sun observations carried out to provide orientation information (Budd 1965). For this traverse, strain grid distances were measured by tape, other distances were observed using a sledge-wheel, directions were taken by compass and heights determined by precise barometer (Corry 1986a, 1996).

In late 1964 the previous season's traverse and strain grids were re-surveyed and the centre line was extended northwards to T5; time and other factors had prevented this northern leg from being established in the previous year (see Figure 2). The 1963 astrofixes were repeated, and resection observations to rock features were also made to provide a check on the absolute velocity results of the astrofixes (Budd 1965). A relative surface elevation profile over the traverse route was measured using digital barometers with slopes being checked by theodolite at numerous points (Budd 1965), providing the first extensive surface elevation information on the AIS. Also in 1965, the front of the AIS was mapped by radar, to determine the amount of ice lost in iceberg calving since previous measurements.

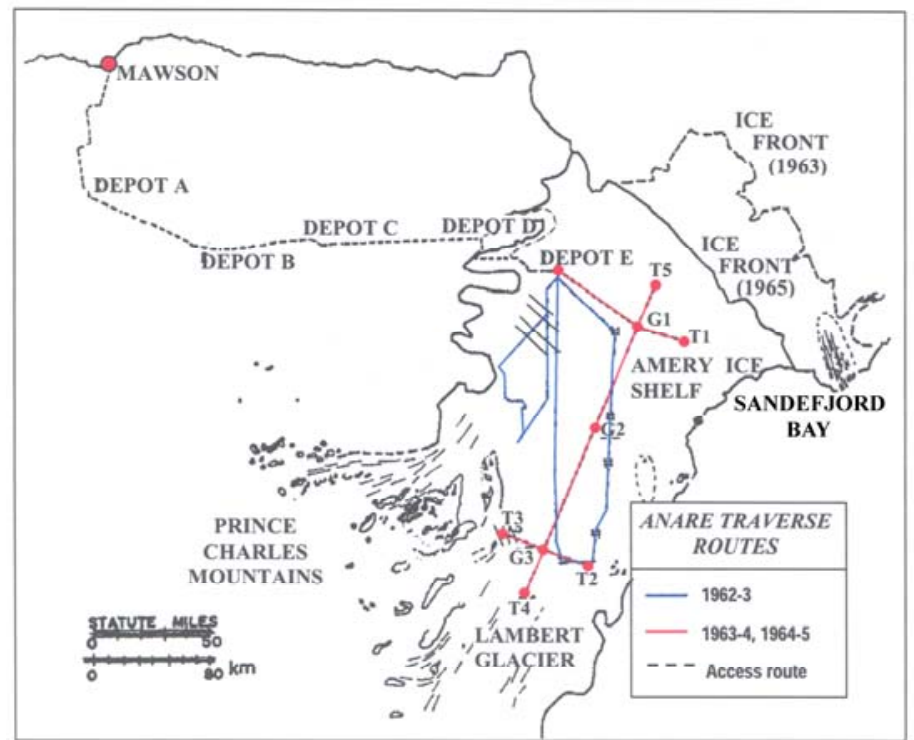

FIGURE 2. Location of the Amery Ice Shelf ANARE traverse routes 1962-65. Source: Phillips (1999), based on the original from Budd et al. (1967).

1968-70

The Amery Ice Shelf Project involved a team spending the winter of 1968 on the AIS, operating a meteorological station and carrying out thermal ice drilling, and then completing a summer field program of survey observations to provide a set of extensive glaciological observations for the ice shelf (Corry 1986b). This project was designed to use much higher-level survey equipment than the previous programs on the AIS and as such was completed using a MRA2 tellurometer, Wild T3 theodolite and an automatic optical level.

As a result of limited logistics, each leg of the network was surveyed with the levelling being carried out on the outward leg and the tellurometer/theodolite work on 
the return leg. Survey poles were placed at high points determined by the levelling, which attempted to follow the route of the previous network, as most of the earlier placed wooden marker stakes were buried or had been ablated out (Corry 1986b). These survey poles were $9 \mathrm{~m}$ (or $6 \mathrm{~m}$ at the southern points) steel poles extending $6 \mathrm{~m}$ (or $4 \mathrm{~m}$ ) above the snow surface (Corry 1996) and were later referred to as 'Corry' poles, named after the surveyor in charge of placing them. The stakes at the three strain grid quadrilaterals at G1, G2 and G3 had originally been marked with much higher bamboo canes than the other locations and could therefore be relocated and subsequently replaced by 'Corry' poles.

The field survey started at G1, following the centre line of the ice shelf southwards to T4, before heading east to T2 and west to T3 at Jetty Peninsula (see Figure 2). Barometric levelling was then carried out at Jetty Peninsula to provide height information for the surface of Beaver Lake (Corry 1986b). Retracing the route back to G1, the survey then continued west towards depot E and north to T5 (see Figure 2). In January 1969 the traverse was extended north of T5 and levelling was carried out to within metres of the ice shelf front (Corry 1987). Several observations to surrounding rock sites connected the survey to fixed points and a levelling run from G1 to Sandefjord Bay provided a connection to the ocean surface (Corry 1986b). This concluded the 1968/69 campaign, the network now consisting of 88 steel pole markers covering about $500 \mathrm{~km}$ (Corry 1996).

The height of the 'Corry' poles prevented the survey equipment from being set up over the mark and therefore, for the distance measurements, the tellurometer was set up as close to the pole as possible and elevated by $3 \mathrm{~m}$ to reduce ground reflection errors while the direction measurements were observed close to the pole and connected to the traverse station via eccentric observations (Linton-Smith 1991) (see Plate 3).
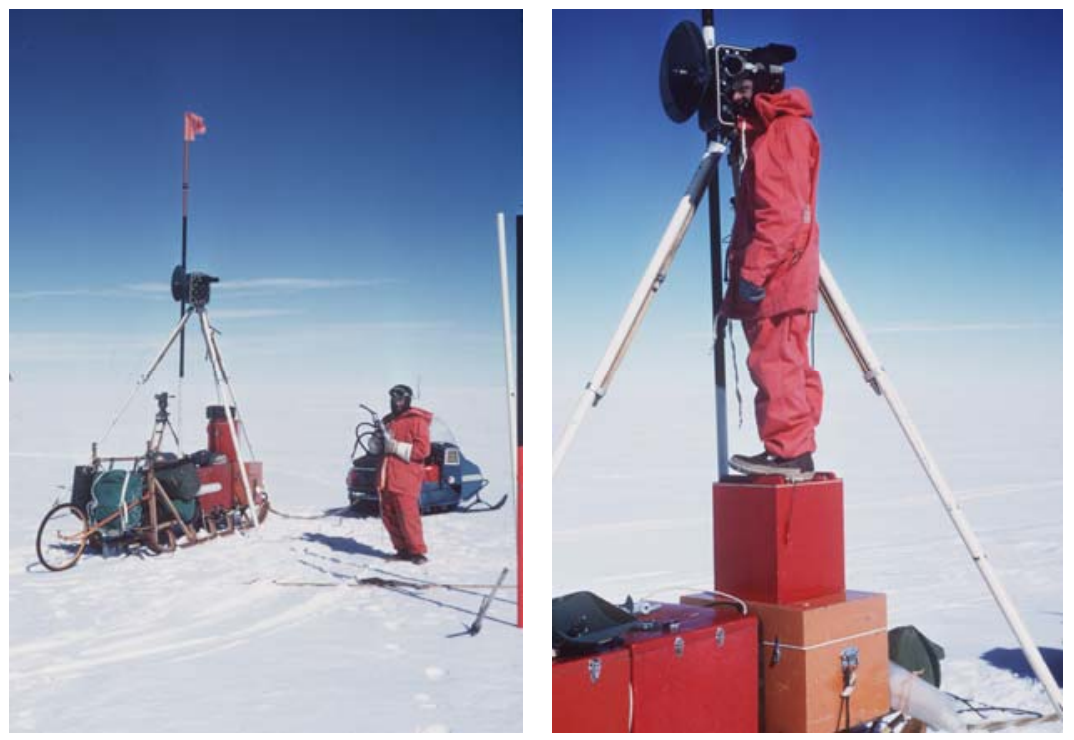

Plate 3. MRA2 tellurometer set-up showing Max Corry at a 'Corry' pole in 1970. Sledge-wheel and theodolite are visible on the left. Photographs by Norman LintonSmith, Australian Government Antarctic Division (c) Commonwealth of Australia.

It was initially planned to re-observe the entire traverse during the 1968/69 field season in order to determine the ice movement at each 'Corry' pole and to measure snow 
accumulation. However, owing to adverse weather conditions throughout autumn and winter, this could not be achieved. The Amery Ice Shelf Project was therefore extended into the following 1969/70 summer season, when the network was remeasured using tellurometer and theodolite and the levelling route extended southwards for another 30$50 \mathrm{~km}$ (Budd et al. 1982, Corry 1987). According to the log book of the trip, the levelling run had to be terminated after only $17 \mathrm{~km}$ (based on sledge-wheel readings) owing to the deteriorating eroded surface caused by melt. During this survey, observations were again made between the same traverse and rock sites providing a connection to the 1968/69 survey (Corry 1987). Also in this season, a newly designed ground-based radio echo sounder (RES) (see Plate 4) was used to provide ice thickness measurements along the traverse route (Budd et al. 1982).

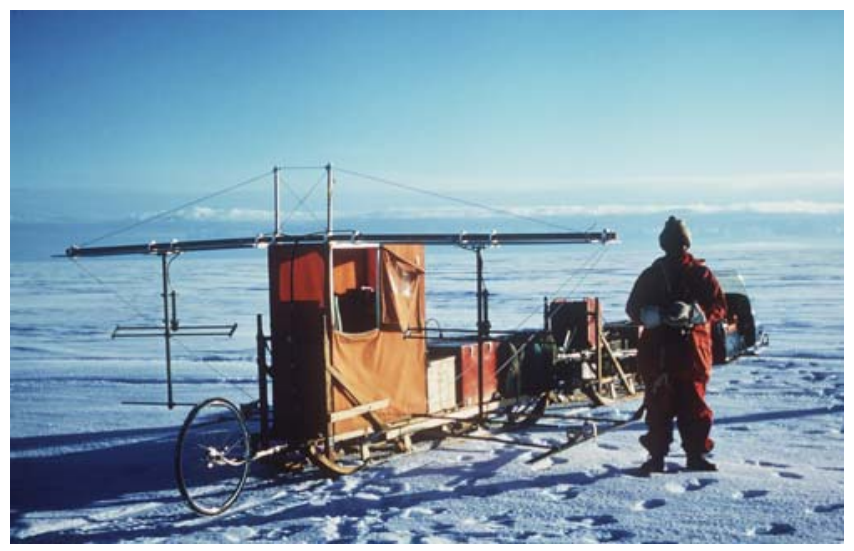

Plate 4. Alan Foster with ice radar sledge in 1970. Photograph by Norman LintonSmith, Australian Government Antarctic Division (C) Commonwealth of Australia.

The Amery Ice Shelf Project resulted in several scientific firsts as described by Corry (1987), among which were:

(1) The first accurate axis optical levelling profile of any ice shelf extending from the seaward edge to the presumed grounding line, along with two transverse elevation profiles, one at the front and one towards the middle of the ice shelf. Coupled with the ice radar (RES) data, this work made a significant contribution to the understanding of the mass balance of the AIS.

(2) The first accurate survey of the movement and strain along a very dynamic ice shelf, referenced to rock sites at both ends of the survey.

The 1968-70 traverses have been reanalysed by King (2002) after he discovered several inconsistencies in the original computation concerning error propagation, a large misclose, and the traverse being reduced to a different ellipsoid than that of the control coordinates. Correction of these errors resulted in the shift of some station coordinates by up to $3-4 \mathrm{~km}$. The resulting set of station coordinates by King is the most accurate, reliable and consistent dataset that forms the basis for long-term studies of the Amery Ice Shelf (King 2002).

1971-74

The following series of field surveys focussed on collecting information on the ice flowing into the AIS and so, in the Antarctic summer of 1971/72, eleven sites were 
established between the $1500 \mathrm{~m}$ and $2000 \mathrm{~m}$ elevation contours around the southern end of the Lambert Glacier Drainage Basin (LGB) (Allison 1979). These markers were positioned through a tellurometer/theodolite traverse that was closed at a rock site on the southern end of the Mawson Escarpment. Small $(100 \mathrm{~m})$ strain grids were also measured at each site. Elevations at the markers were determined to $2^{\text {nd }}$ order accuracy by reciprocal vertical angles to stations on surrounding mountains, and gravity measurements were also made at the sites (Allison 1979). Two years later, in 1973/74, the survey was repeated in order to determine ice velocities at the traverse sites (Allison 1979). During both seasons, aerial RES data were collected using a $100 \mathrm{MHz}$ echo sounder and covering an area of $200,000 \mathrm{~km}^{2}$ with estimated positioning errors for the flight lines of up to $\sim 5 \mathrm{~km}$ (Morgan \& Budd 1975).

During the next few years no spatial science fieldwork took place on the Amery Ice Shelf since the large amount of data collected provided a good first understanding of the AIS and activities concentrated on other areas in Antarctica. However, the arrival of the GPS technology opened up new possibilities and shifted the focus back to the AIS in the late 1980s.

\section{GPS surveys (1988 - present)}

The 1980s saw the advent of GPS technology, which allowed new projects to be attempted at far more remote regions of the AIS than were previously feasible. This technological advance plus improvements in logistical capabilities (e.g. helicopter and skidoo transport) allowed a much greater number of locations to be sampled and a larger amount of data to be collected and analysed at varying levels of precision. These GPS surveys can be split into two eras:

(1) Pre-1993/94: the GPS equipment used and the GPS system in place was at such a level that only low-precision observations could be made during limited observation windows.

(2) Post-1993/94: from 1993/94 to the present, GPS surveys have been carried out over extended time periods and to high levels of precision, due to major improvements in the GPS system, field equipment and processing techniques.

The field techniques and scientific purpose for each of the major GPS surveys in the AIS/LGB region were different in each season; however, most were undertaken to provide ice velocity/strain information or ground truthing for remote-sensing projects. The following discussion illustrates the advancement of GPS technology over the last 20 years via its implementation in the AIS region. Figure 3 shows the location of the major GPS field surveys conducted. 


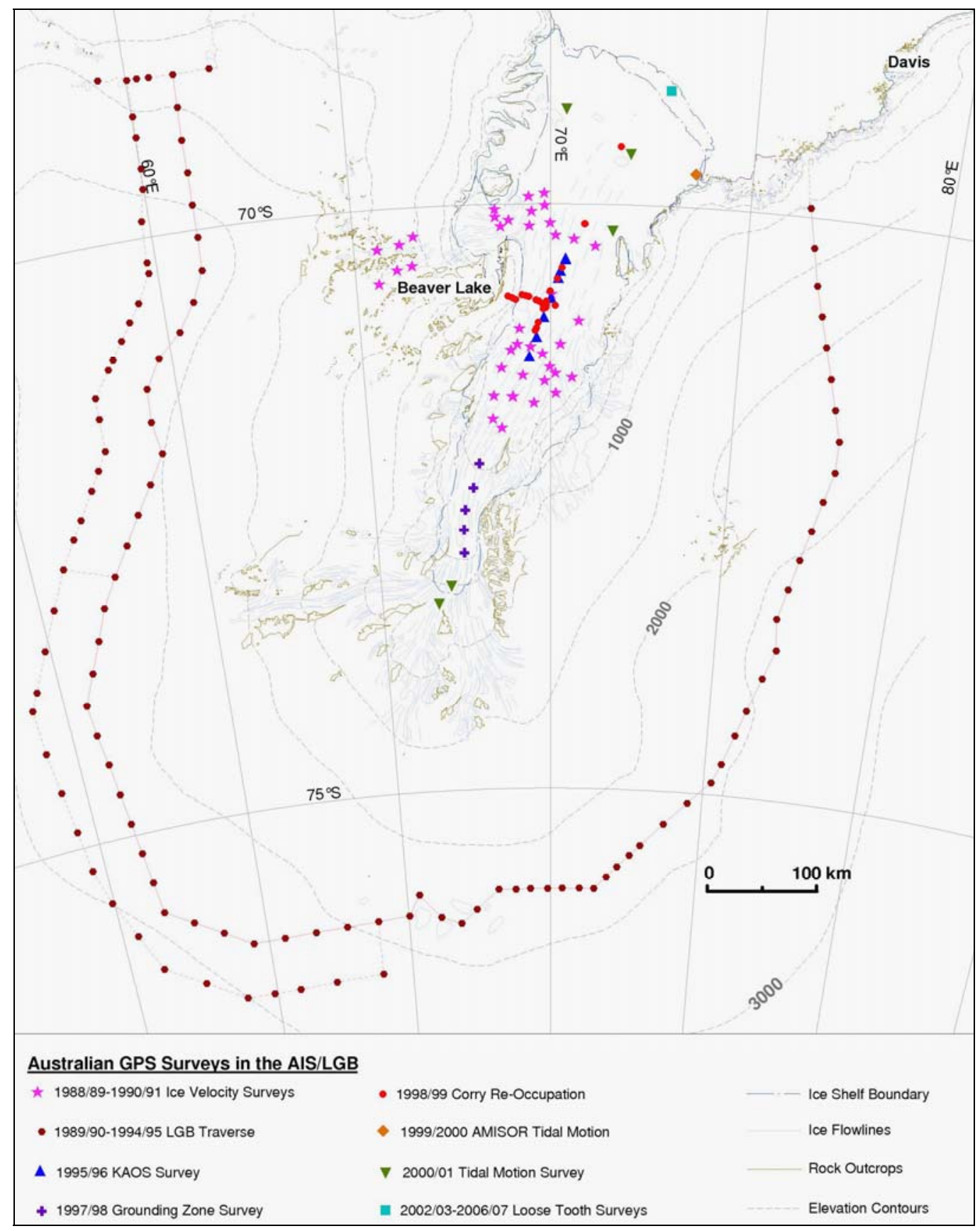

FIGURE 3. Locations of major Australian GPS surveys in the AIS/LGB region.

AIS velocity survey (1988/89, 1989/90 and 1990/91)

The first GPS surveys by ANARE on the AIS were undertaken as part of the LambertAmery Regional Glaciology Experiment (LARGE) to observe ice dynamics, mass flux and grounding zone characteristics of the AIS and lower Lambert Glacier (now known to actually have been the southern AIS, see Fricker et al. 2002a) (Allison 1991). Equipment used was single-frequency Wild Magnavox WM101 (1988/89) and dualfrequency WM102 (1989/90 and 1990/91) GPS receivers. In this project, marker poles were placed in 'gate' formations across specific areas of ice flowing into the ice shelf and were observed/re-observed with GPS over the three field seasons (Allison 1991). 
During this work, two of the 1968-70 'Corry' poles were also discovered and positioned with GPS. Initial position results were highly degraded (1-10 m precision) due to the single-frequency receivers, very long baselines, low satellite numbers, short observation windows (0.5-2 hours), high latitude, high levels of ionospheric disturbances (sunspot maximum) and bad weather limiting the number of possible reoccupations in 1989/90 (Allison 1991). Gravity, barometric levelling and airborne radio-echo sounding (RES) measurements were also collected across the northern AIS during this time to provide further information on the structure of the ice shelf (Allison 1991).

\section{LGB traverse (1989/90, 1990/91 and 1992/93)}

As part of the LARGE experiment, a series of five traverses was completed that placed and positioned a network of permanent ice marker poles (at $30 \mathrm{~km}$ spacing) to observe ice dynamics and surface slope approximately along the $2500 \mathrm{~m}$ contour of the LGB between Mawson and Law Base (Kiernan 2001) (see Plate 5). The GPS equipment used for the first three of these traverses was dual-frequency WM102 instruments (Kiernan 2001). Again, the long baselines (up to $700 \mathrm{~km}$ ), low numbers of satellites, short observation windows, high latitude and high levels of ionospheric disturbances affected these surveys and caused initial results to be of a low precision ( 1-10 m) (Manson et al. 2000, Kiernan 2001).

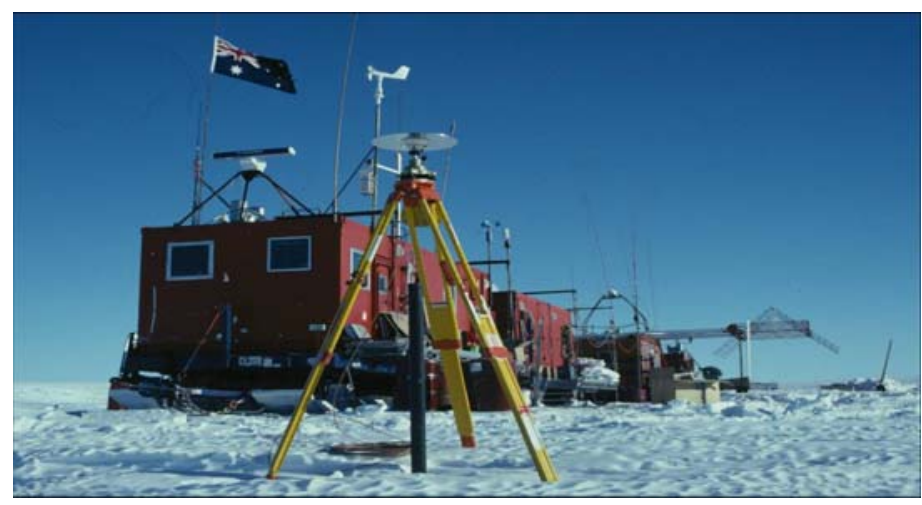

PLATE 5. Typical GPS station setup during the LGB traverse, with ice radar measurements also being made (see background). Photograph by Australian Government Antarctic Division (C) Commonwealth of Australia.

\section{LGB traverse (1993/94 and 1994/95)}

The final two LGB traverses completed the traverse route from Mawson to Law Base during the summers of 1993/94 and 1994/95. In these surveys, 72 ice marker poles were located/relocated using new Leica SR299 dual-frequency receivers (Kiernan 2001). Also, at this time, the GPS satellite constellation had reached its Initial Operational Capability (declared 8 Dec 1993 when 24 satellites were in orbit) and ionospheric activity had eased. These improvements in equipment, number of satellites and ionospheric conditions in conjunction with modern data processing techniques allowed the final ice velocities for the LGB traverse sites to be determined with precisions of 1$10 \mathrm{~cm} / \mathrm{yr}$ (Hurd 2002). 


\section{KAOS (1995/96)}

The KAOS (Kinematic Amery Over-Snow) survey was undertaken to (i) provide ground truthing data for validation of a new elevation model of the AIS created from ERS satellite altimeter data, (ii) re-measure surface height and velocity along a section of the 1968-70 optical traverse line, and (iii) observe the tidal motion of the ice shelf (Phillips 1999). This survey used three Leica SR299 dual-frequency receivers: one as a base station at a fixed rock site approximately $60 \mathrm{~km}$ from the ice shelf survey, the second as a series of local base stations on the ice shelf and the third mounted on a skidoo to collect kinematic GPS surface profiles (Phillips 1999). The kinematic profiles were collected in a grid formation, so that the GPS data could be used to create a new digital elevation model of the area that coincided with several cross-over points of the ERS altimeters (Phillips et al. 1998). Whilst collecting the kinematic data, the surveyors also discovered a number of the original 1968 'Corry' poles, which were reoccupied to provide a long-term velocity estimate for these sites (Allison 1995).

\section{Grounding zone survey (1997/98)}

Phillips et al. (1996) redefined the AIS grounding zone position to be around $73^{\circ} \mathrm{S}$, approximately $200 \mathrm{~km}$ south of previous estimates. To confirm the southern extent of the floating ice shelf, six Leica SR9500 dual-frequency GPS stations were deployed and ran continuously for up to 4 days to collect vertical and horizontal motion data and therefore indicate the range of tidal motion in this region (King 2002).

\section{Corry/KAOS reoccupation survey (1998/99)}

To strengthen knowledge of velocity and strain on the ice shelf and obtain a 30-year time-span of observations, a GPS survey was undertaken with the aim of re-observing all available 1968-70 'Corry' poles using GPS (King 2002). In this survey, 22 'Corry' poles, 4 KAOS poles and the 1968 G1, G2 and G3 strain grids were able to be located and surveyed with dual-frequency (Leica SR9500 and Ashtech Z12) GPS equipment (King 2002). For the duration of the survey (11 days), a local GPS base station was installed near G3 providing important information on the tidal motion in this region of the AIS (King et al. 2000).

\section{Tidal motion surveys (1999/2000 and 2000/01)}

The commencement of the Amery Ice Shelf Ocean Research (AMISOR) hot water drilling project in 1999/2000 provided the location and personnel to run a continuous GPS site (Leica CRS1000) to measure tidal motion at the front of the AIS for 31 days (Craven et al. 2000). In this same season, the 1997/98 grounding zone sites were also re-observed for a short period with GPS to provide multi-year velocity data at these sites.

The success of the previous seasons' GPS data in providing new and important tidal information led to the development of a project dedicated to observing tidal motion at specific points along the length of the AIS (King 2002). This information was required for calibrating ocean circulation models and further understanding the ice shelf/ocean dynamics (King 2002). In the summer of 2000/01, six autonomous Leica CRS1000 receivers were deployed powered by batteries and solar panels to allow continuous data collection at widely spaced locations over the summer. Kinematic runs were also 
completed on skidoos using Leica SR9500 equipment (see Plate 6) when possible during this time to provide surface profile information for ERS altimeter validation.

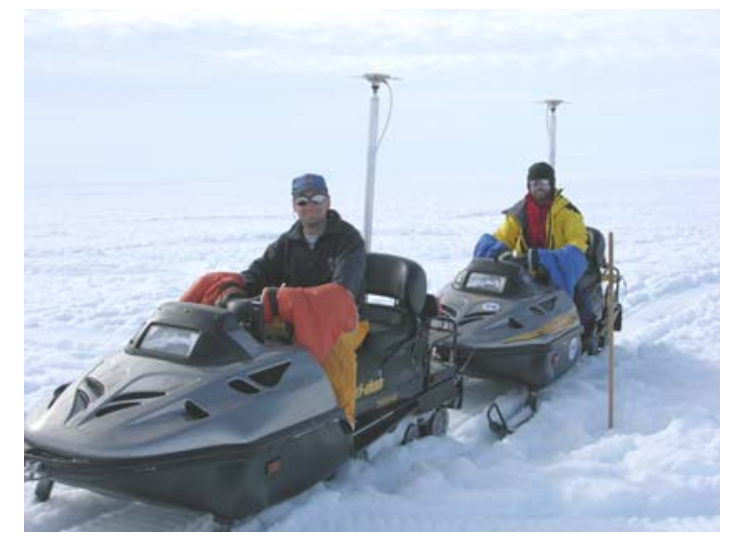

PLATE 6. Kinematic GPS survey on skidoos, January 2005.

\section{Loose Tooth surveys (2002/03 - 2006/07)}

Scientists analysing satellite images of the AIS identified a $30 \mathrm{~km} \times 30 \mathrm{~km}$ area at the front of the ice shelf (now known as the 'Loose Tooth') that has a number of dormant and active rift systems (Fricker et al. 2002b). In order to understand mechanisms behind iceberg calving, GPS and seismic data have been collected each summer since 2002/03 around the tip of one of the active rifts that will eventually cause the iceberg to calve from the shelf (Bassis et al. 2005). The GPS network in each survey consisted of between 6 and 12 sites spanning the area immediately behind, in front and either side of the rift tip (see Plate 7). The equipment used was a combination of Leica, Ashtech and Trimble dual-frequency receivers powered by solar panels and collecting data for between 2 and 59 days.

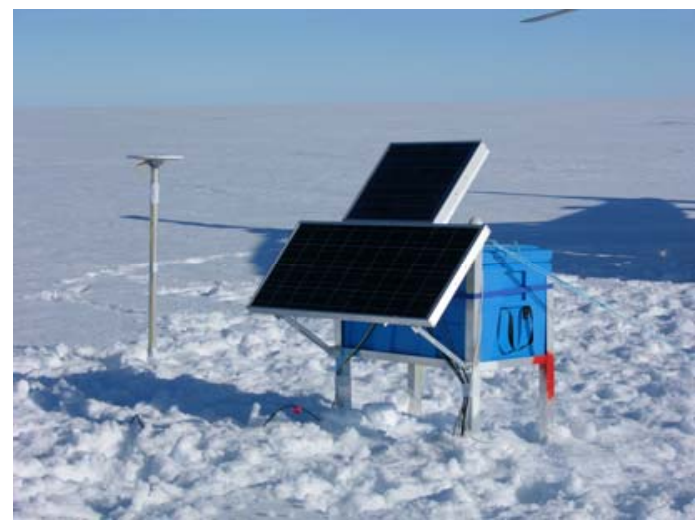

PLATE 7. GPS site on the 'Loose Tooth’ in 2004/05.

\section{Satellite remote-sensing data analysis}

Satellite remote-sensing data allow extensive and relatively precise mapping of vast and/or remote areas that would otherwise not be possible from land-based surveys. The AIS/LGB is an example of an area for which satellite remote sensing provides scientists 
with much valuable information that can also be validated using the previously described ground-based observations. There are many types and epochs of satellite data available to scientists in the international community and therefore in recent times there have been many studies carried out which include observations in the AIS region (e.g. Rignot 2002, Liu \& Jezek 2004, Raup et al. 2005). This section briefly introduces three types of satellite remote-sensing data available over the AIS and, as an example, outlines the work of some projects that specifically focus on improving the understanding of the dynamics and physical attributes of the AIS.

\section{Satellite imagery}

The Landsat program has been running for over 30 years, providing visible and infrared satellite images of the Earth (NASA 2007a). These images provide useful feature identification for glaciological studies, which aid in identifying characteristics of different regions of the ice. For example, Swithinbank (1988) used Landsat images to create a detailed map of the surface features of the AIS/LGB including flow-lines, melt water and crevassed areas while Hambrey \& Dowdeswell (1994) used Landsat MSS (Multi Spectral Scanner) images to investigate historic ice flow patterns on the AIS. In combination with other data, Landsat imagery has also been used to track the ice shelf front over many years in order to study iceberg calving (Fricker et al. 2002b).

\section{Satellite altimetry}

Satellite altimeters measure the distance between the satellite (of known orbit) and the ground or ocean surface, from which surface elevations can be calculated. The first satellite radar altimeter to provide coverage over the AIS was the Seasat altimeter (operational in 1978), and from these data Brooks et al. (1983) and Zwally et al. (1987) generated the first detailed surface elevation maps of the AIS.

The second radar altimeter to collect data over the AIS was Geosat, which was operational between 1985 and 1990. The data collected by Geosat were used by both Herzfeld et al. (1993) and Lingle et al. (1994) to create new digital elevation models (DEMs) of the AIS in order to investigate elevation changes between 1978 and the 1980s.

The European Remote-sensing Satellites ERS-1 (operational 1991-99) and ERS-2 (launched in 1995) carry various instruments including a radar altimeter and synthetic aperture radar (SAR) (ESA 2007a). Data from the ERS-1 satellite in particular have been used by many authors (e.g. Ridley et al. 1993, Bamber \& Gomez-Dans 2005) to derive DEMs of Antarctica as (i) it collected data to $82^{\circ} \mathrm{S}$, (ii) its operation was modified to allow better tracking over areas of ice, and (iii) its orbit was varied on two occasions to allow a smaller separation distance of the ground tracks. The most extensive use of ERS-1 altimeter data on the AIS was undertaken by Phillips (1999) in which she and her collaborators generated DEMs of the AIS and the AIS/LGB system (Fricker et al. 2000a) and used these DEMs to investigate the mass balance of the system (Fricker et al. 2000b) and the distribution of marine ice beneath the AIS (Fricker et al. 2001). The ERS altimeter DEMs were also compared with results from the KAOS GPS survey which showed that ERS altimeters can closely reproduce the surface topography of the AIS (to within 1-2 m) (Phillips et al. 1998).

The most recent advance in remote sensing technology is the Ice, Cloud, and land Elevation Satellite (ICESat), which was launched in January 2003 and is the first laser 
altimeter operating in a polar orbit (NASA 2007b). It carries three Geoscience Laser Altimeter System (GLAS) altimeters which have been shown to deliver high-quality elevation data with a high level of horizontal resolution ( $\sim 70 \mathrm{~m}$ footprint and $\sim 170 \mathrm{~m}$ along-track spacing) and a relative accuracy of $\pm 0.14 \mathrm{~m}$ (Shuman et al. 2006). On the AIS, ICESat data have recently been used to investigate rift topography and rift widening of the 'Loose Tooth' system (Fricker et al. 2005a) and will be very important to future research on the ice shelf.

\section{Synthetic aperture radar (SAR)}

Interferometric synthetic aperture radar (InSAR) is an imaging technique used to map the topography of a surface and its changes over time at a high resolution, based on a pair of radar images acquired over the same area from almost the same satellite position (Rosen et al. 2000). Although SAR instruments have been accommodated on several satellites, RADARSAT (launched in 1995) was the first to deliver complete coverage of the Antarctic continent (Jezek 1999), and thus initiated numerous studies. For example, Young \& Hyland (2002) used RADARSAT data to generate a dense network of velocity estimates (see Plate 8 ) and to determine strain rates over the AIS, while Fricker et al. (2002b) investigated the iceberg-calving cycle on the AIS. A combination of SAR data and satellite imagery was used to monitor the propagation of the 'Loose Tooth' rift system (Fricker et al. 2005b).

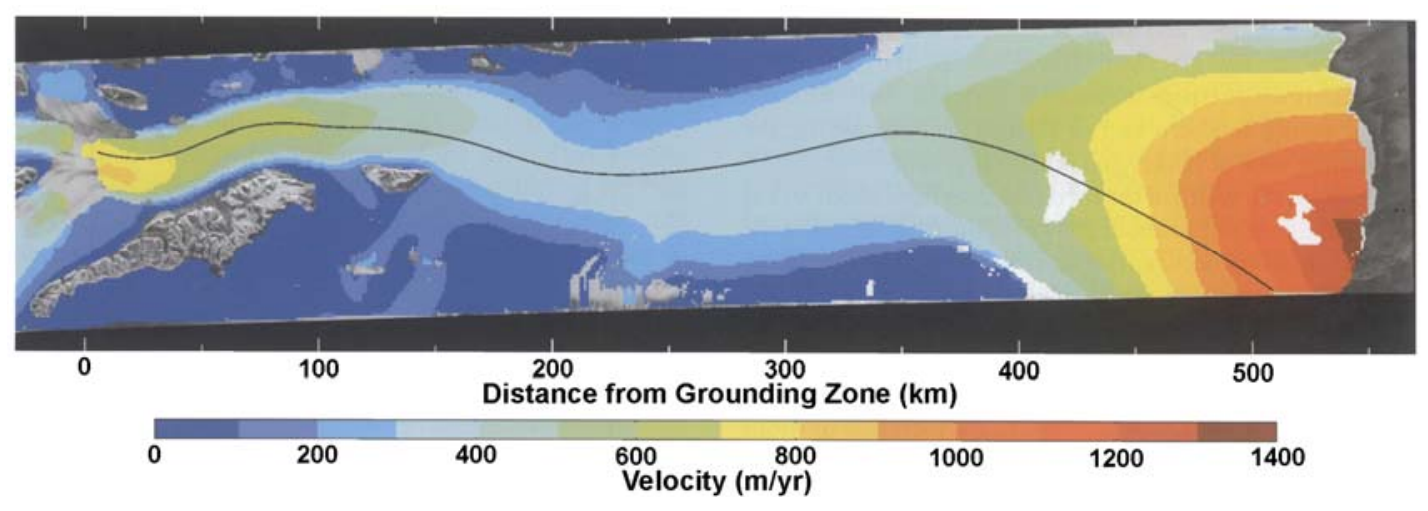

PLATE 8. Distribution of ice velocities over the AIS. Source: Young \& Hyland (2002).

\section{Summary of major results from spatial data collected on the AIS by Australian programs}

The scientists who have collected and analysed the AIS spatial data have produced a wide body of work that defines various aspects of the ice shelf and its surroundings. The spatial data collected over the AIS during the past 50 years both on the ground and from satellites have allowed scientists to progress from an initial, basic understanding of the physical characteristics of the AIS to now fine-tuning their knowledge of the entire glacier/ice-shelf/ocean system. These studies are important as they provide the knowledge required to understand the role of this region in the Antarctic system and to allow future monitoring of the effects of climate change in this sensitive region. The current assessment of the AIS is summarised below: 
(1) It extends $550 \mathrm{~km}$ in length from $\sim 73^{\circ} \mathrm{S}$ to $\sim 68.5^{\circ} \mathrm{S}$ (Fricker et al. 2002a, Young \& Hyland 2002).

(2) The width of the ice shelf increases from about $40 \mathrm{~km}$ at the grounding zone to about $200 \mathrm{~km}$ at the front (Young \& Hyland 2002).

(3) The area of the AIS is approximately $71,260 \mathrm{~km}^{2}$ (Fricker et al. 2002a).

(4) The thickness of the ice shelf varies from $2500 \mathrm{~m}$ at the grounding zone to $200 \mathrm{~m}$ at the front (Budd et al. 1982, Fricker et al. 2002a) with some areas of sea-ice accretion and some areas of melt at the ice/ocean interface (Fricker et al. 2001).

(5) Ice velocities range from $300 \mathrm{~m} / \mathrm{yr}$ to $1350 \mathrm{~m} / \mathrm{yr}$ (Young \& Hyland 2002).

(6) The AIS/LGB system is currently thought to be in a state of slightly positive mass balance (Fricker et al. 2000b).

The results of the projects described in this paper have been published previously by the researchers involved (refer to reference list for details). The major findings from these studies of the AIS/LGB are (in chronological order):

(1) Identification of a significant iceberg calving event in late 1963 (Budd 1966).

(2) Initial definition of the ice shelf extent, topography and dynamics, mainly in the northern half of the ice shelf (Budd 1966, Budd et al. 1967, Corry 1986a). Budd et al. (1982) presented the results of the 1968-70 surveys which included the identification of a grounding line just south of $\mathrm{T} 4$, determination of initial ice velocity values (see Figure 4) and noting that strain rates were the primary cause of ice shelf thinning.

(3) The major results of the 1968-70 RES measurements were reported by Morgan \& Budd (1975), most importantly mapping the bedrock below the ice, determining ice thickness values in the AIS/LGB region and finding a maximum ice thickness of $2500 \mathrm{~m}$.

(4) Using field survey data from the 1968-74 campaigns, combined with the RES ice thickness data (Morgan \& Budd 1975), Allison (1979) estimated a mass budget of the Lambert Glacier Drainage Basin of $+12 \mathrm{Gt} / \mathrm{yr}$. This assessment had quite a large error budget due mainly to the lack of available snow-accumulation values across the LGB.

(5) The LGB traverses provided a large amount of glaciological information regarding the ice flowing into the AIS. The main results arising from the GPS data collected during the traverses were ice velocities and identification of the major ice streams, surface elevation and slope and, in combination with other information, mass flux values for balance calculations (Kiernan 2001, Hurd 2002).

(6) Ice velocities over the ice shelf and the northern LGB glaciers were first discussed in Allison (1991) and later King (2002) provided updated velocity and strain values for many of the ice markers in the centre of the ice shelf including long-term velocities for sites observed in both the 1960s and 1990s.

(7) ERS satellite altimeter data were used by Phillips (1999) and collaborators to produce the most extensive physical maps of the AIS. These studies generated several important outcomes including (i) redefinition of the grounding zone to between $73.2^{\circ} \mathrm{S}$ and $73.3^{\circ} \mathrm{S}$, about $240 \mathrm{~km}$ further upstream than previously proposed by Budd et al. (1982), identified in the AIS DEM and the 1997/98 GPS data (Fricker et al. 2002a), (ii) the fact that marine ice accretion on the AIS accounts for about 9\% of the ice shelf volume (Fricker et al. 2001), (iii) improved AIS/LGB system mass balance calculation that also incorporated information from the LGB 
traverses (Fricker et al. 2000b), and (iv) production of surface elevation maps of the AIS and LGB that employed GPS data for ground truthing (Phillips et al. 1998, Fricker et al. 2000a).

(8) The analysis of quasi-continuous GPS observations on the AIS produced valuable information about its tidal characteristics and the ocean circulation beneath the ice shelf (Phillips et al. 1996, King et al. 2000, King 2002). These studies revealed tidal signals of 1-2 $\mathrm{m}$ across the AIS, and the GPS data have been used to improve and validate tide models (Padman et al. 2002, King et al. 2005).

(9) Mapping of surface velocities over the entire AIS from InSAR data showed that velocities decreased from around $800 \mathrm{~m} / \mathrm{yr}$ at the grounding zone to around 300 $\mathrm{m} / \mathrm{yr}$, and then increased to a maximum of about $1350 \mathrm{~m} / \mathrm{yr}$ at the front (see Plate 8), while strain rates varied systematically across and along the ice shelf (Young \& Hyland 2002). Similar velocity values were obtained by Joughin (2002) who employed a different data processing approach.

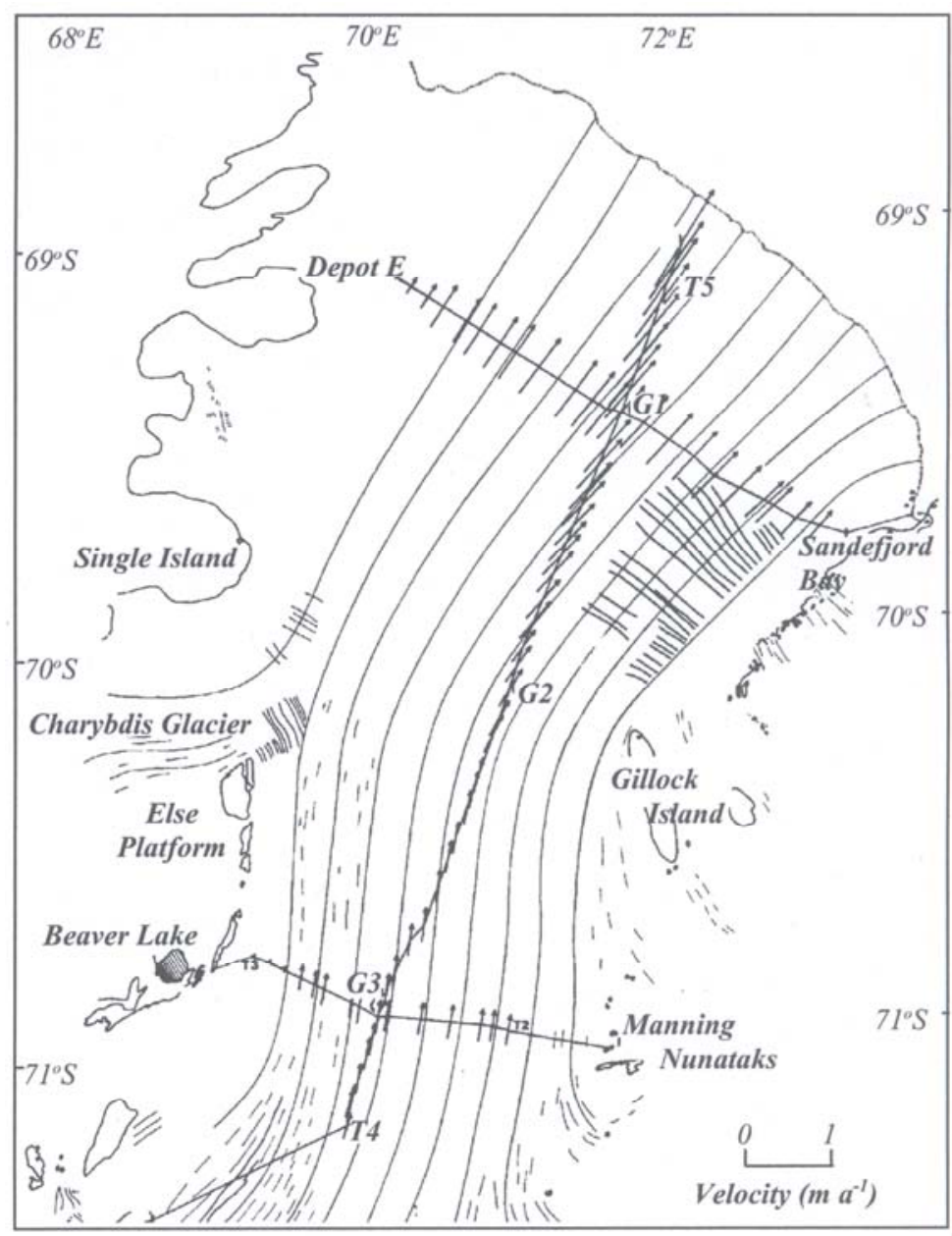

FIGURE 4. Surface ice flow velocity vectors on the Amery Ice Shelf determined during the 1968-70 surveys, together with estimated flow-lines from satellite imagery.

Source: Phillips (1999), based on the original from Budd et al. (1982).

(10) Understanding of rift mechanics and iceberg calving processes around the 'Loose Tooth' using GPS in conjunction with seismic and satellite data. Rift propagation 
rates of about $4 \mathrm{~m} /$ day and evidence of seasonal dependence (rifts propagate faster in summer than in winter) were found by Fricker et al. (2005b). Propagation occurs in episodic bursts lasting about four hours, separated by several (10-20) days (Bassis et al. 2005) and the collection of ice and snow trapped inside the rift (often called mélange) may potentially be important for rifting (Fricker et al. 2005a).

\section{Future opportunities}

Ground-based and remote-sensing observations are set to continue, with increasing measurement precision, during the International Polar Year 2007-08 and beyond, and these will surely have a large impact on the improvement of the current knowledge of the dynamics of the AIS.

ICESat will continue to provide valuable data for ice sheet mass balance and related studies in the polar regions. For example, Fricker et al. (2007) have recently detected an active sub-glacial water system in West Antarctica, based on ICESat observations over 3 years.

The Gravity Recovery and Climate Experiment (GRACE), launched in March 2002, consists of two satellites circling the Earth in tandem and measuring gravity to map changes in the Earth's mass distribution. GRACE has already produced impressive results in the Antarctic region (e.g. Velicogna \& Wahr 2006, GRACE 2007) and, as more data become available, it will be possible to reveal longer-term trends.

The CryoSat-2 mission is planned for launch in 2009, after the loss of the first CryoSat in October 2005 due to a launch failure, with the objective to measure the thickness of the polar ice sheets and floating sea ice precisely in order to provide conclusive evidence as to whether there is a trend towards diminishing polar ice cover and to investigate the relationship between ice and global climate. CryoSat-2 will carry a sophisticated radar altimeter called SIRAL (Synthetic Aperture Radar Interferometric Radar Altimeter), achieving a spatial resolution of $250 \mathrm{~m}$ (Wingham et al. 2006, ESA 2007b).

Data from these sensors, in combination with ground-based observations, will provide a detailed and highly accurate picture of the AIS and the entire Antarctic ice sheets, giving scientists new insights into the role that Antarctica plays in global climate change.

\section{Concluding remarks}

In this paper we have charted the recent history of spatial information gathering in general by looking at the work carried out in a specific region over the past 50 years. The use of spatial techniques, which have evolved from instruments such as barometers, compasses, optical theodolites and levels in the 1960s to GPS equipment and satellite data in recent times, provided invaluable insight into the structure, dynamics and environmental interactions of the Amery Ice Shelf, allowing new discoveries to be made as technologies improved. Australian activities in the region have made a significant contribution to the advance of scientific knowledge. Future projects will benefit from the next generation of spatial observations and with the current knowledge as a basis will allow scientists to use the AIS region for monitoring the effects of climate change in this region. 


\section{Acknowledgements}

This paper is a modified and extended version of a presentation given at the Spatial Sciences Institute Conference (SSC2007) in Hobart, Australia, 14-18 May 2007. Thanks are due to Max Corry for the clarification of events during the Amery Ice Shelf Project (1968-70). The research projects presented in this paper were supported by many agencies and funded by numerous sources, including Australian Research Council (ARC) grants, Australian Antarctic Science (AAS) grants, Australian Antarctic Climate and Ecosystems Cooperative Research Centre (ACE-CRC) funding, US National Science Foundation (NSF) grants and NASA grants.

\section{REFERENCES}

Allison, I. (1979) 'The mass budget of the Lambert Glacier Drainage Basin, Antarctica', Journal of Glaciology 22(87), pp. 223-35.

AlLISON, I. (1991) 'The Lambert Glacier/Amery Ice Shelf study: 1988-1991', Aurora 10(4), pp. 22-25.

AlLISON, I. (1995) 'Surveying the Amery Ice Shelf', ANARE News, Spring/Summer 1995-96, p. 12.

Allison, I. (2001) 'Peephole through the ice: The AMISOR project', Australian Antarctic Magazine 1, Autumn 2001, pp. 20-21.

BAMBER, J. \& GOMEZ-DANS, J.L. (2005) 'The accuracy of digital elevation models of the Antarctic continent', Earth and Planetary Science Letters 237, pp. 516-23.

BAssis, J.N., COlEmAn, R., FricKer, H.A. \& Minster, J.B. (2005) 'Episodic propagation of a rift on the Amery Ice Shelf, East Antarctica', Geophysical Research Letters 32(6), L06502, DOI:10.1029/2004GL022048.

BroOKS, R.L., Williams, R.S.J., FERRIGNO, J.G. \& KraBiLl, W.B. (1983) 'Amery Ice Shelf topography from satellite radar altimetry’, in Oliver, R.L., James, P.R. \& Jago, J.B. (eds) Antarctic earth science, Cambridge University Press, Cambridge, pp. 44145.

BudD, W. (1965) 'Glaciological survey of the Amery Ice Shelf', Antarctic 4(3), pp. 158-59.

BuDD, W. (1966) 'The dynamics of the Amery Ice Shelf', Journal of Glaciology 6(45), pp. 335-58.

BuDD, W.F., CORRY, M.J. \& JACKA, T.H. (1982) 'Results from the Amery Ice Shelf Project', Annals of Glaciology 3, pp. 36-41.

BudD, W., LANDON SMith, I. \& WisharT, E. (1967) 'The Amery Ice Shelf', in Oura, H. (ed.) The Physics of snow and ice, Proceedings of the International Conference on Low Temperature Science, Institute of Low Temperature Science, Hokkaido University, Sapporo, Japan, pp. 447-67.

Corry, M. (1986a) 'The Amery Ice Shelf saga: Part 1 - pre 1968', Aurora 6(1), pp. 1720.

CORRY, M. (1986b) 'The Amery Ice Shelf saga - Part 2: The Amery Ice Shelf Project 1968', Aurora 6(2), pp. 28-34.

CORRY, M. (1987) 'The Amery Ice Shelf saga: Part 3 - 1969-70', Aurora 6(3), pp. 2529.

CORRY, M. (1996) 'Those Amery Ice Shelf glaciological marker snowpoles', Aurora 15(4), pp. 18-20. 
Craven, M., Brand, R., Elcheikh, A. \& Jones, N. (2000) 'Summer field report for Amery Ice Shelf HWD test season: AMISOR-1', internal report, Cooperative Research Centre for the Antarctic and Southern Ocean Environment, Hobart, Australia.

ESA (2007a) http://earth.esa.int/ers/ (accessed 15 October 2007).

ESA (2007b) http://www.esa.int/esaLP/LPcryosat.html (accessed 15 October 2007).

Fricker, H.A., Allison, I., Craven, M., Hyland, G., Ruddell, A., Young, N., Coleman, R., King, M., Krebs, K. \& Popov, S. (2002a) 'Redefinition of the Amery Ice Shelf, East Antarctica, grounding zone’, Journal of Geophysical Research 107(B5), ECV 1/1-1/9.

Fricker, H.A., BAssis, J.N., Minster, B. \& MACAyEAL, D.R. (2005a) 'ICESat's new perspective on ice shelf rifts: The vertical dimension', Geophysical Research Letters 32, L23S08, DOI:10.1029/2005GL025070.

FricKer, H.A., Hyland, G., Coleman, R. \& YounG, N.W. (2000a) 'Digital elevation models for the Lambert Glacier-Amery Ice Shelf system, East Antarctica, from ERS1 satellite radar altimetry', Journal of Glaciology 46(155), pp. 553-60.

Fricker, H.A., Popov, S., Allison, I. \& Young, N. (2001) 'Distribution of marine ice beneath the Amery Ice Shelf', Geophysical Research Letters 28(11), pp. 2241-44.

Fricker, H.A., Scambos, T., Bindschadler, R. \& PADMAN, L. (2007) 'An active subglacial water system in West Antarctica mapped from space’, Science 315, pp. 1544-48.

FriCKER, H.A., WARNER, R.C. \& Allison, I. (2000b) 'Mass balance of the Lambert Glacier-Amery Ice Shelf system, East Antarctica: A comparison of computed balance fluxes and measured fluxes', Journal of Glaciology 46(155), pp. 561-70.

Fricker, H.A., Young, N.W., Allison, I. \& ColemAN, R. (2002b) 'Iceberg calving from the Amery Ice Shelf, East Antarctica’, Annals of Glaciology 34, pp. 241-46.

Fricker, H.A., Young, N.W., Coleman, R., BAssis, J.N. \& Minster, J.B. (2005b) 'Multi-year monitoring of rift propagation on the Amery Ice Shelf, East Antarctica', Geophysical Research Letters 32(2), L02502, DOI:10.1029/2004GL021036.

GRACE (2007) http://www.csr.utexas.edu/grace/ (accessed 15 October 2007).

HAMBREY, M.J. \& DowdeSWELl, J.A. (1994) 'Flow regime of the Lambert GlacierAmery Ice Shelf system, Antarctica: Structural evidence from Landsat imagery', Annals of Glaciology 20, pp. 401-06.

HerzFeld, U.C., LiNGLe, C.S. \& LEE, L.-H. (1993) 'Geostatistical evaluation of satellite radar altimetry for high-resolution mapping of Lambert Glacier, Antarctica', Annals of Glaciology 17, pp. 77-85.

HURD, R. (2002) 'An investigation of glaciological and meteorological parameters in the Lambert Glacier Basin using high precision GPS strategies', unpublished PhD thesis, University of Tasmania, Hobart, Australia.

Jacobs, S.S., Helmer, H.H., DoAke, C.S.M., Jenkins, A. \& Frolich, R.M. (1992) 'Melting of ice shelves and the mass balance of Antarctica', Journal of Glaciology 38(130), pp. 375-87.

JEZEK, K.C. (1999) 'Glaciological properties of the Antarctic ice sheet from RADARSAT-1 synthetic aperture radar imagery’, Annals of Glaciology 29, pp. 28690.

Joughin, I. (2002) 'Ice-sheet velocity mapping: A combined interferometric and speckle-tracking approach’, Annals of Glaciology 34, pp. 195-201. 
KIERNAN, R. (2001) 'Ice sheet surface velocities along the Lambert Glacier Basin traverse route', Research Report No. 23, Antarctic Cooperative Research Centre, University of Tasmania, Hobart, Australia, 76 pp.

KING, M. (2002) 'The dynamics of the Amery Ice Shelf from a combination of terrestrial and space geodetic data', unpublished $\mathrm{PhD}$ thesis, University of Tasmania, Hobart, Australia.

King, M., Nguyen, L.N., Coleman, R. \& Morgan, P. (2000) 'Strategies for high precision processing of GPS measurements with application to the Amery Ice Shelf, East Antarctica', GPS Solutions 4(1), pp. 2-12.

King, M.A., Penna, N.T., Clarke, P.J. \& King, E.C. (2005) 'Validation of ocean tide models around Antarctica using onshore GPS and gravity data', Journal of Geophysical Research 110(B8), B08401, DOI:10.1029/2004JB003390.

LAw, P. (1967) 'Movement of the Amery Ice Shelf', The Polar Record 13(85), pp. 43941.

Lingle, C.S., LeE, L-H., ZWALly, H.J. \& SeISS, T.C. (1994) 'Recent elevation increase on Lambert Glacier, Antarctica, from orbit crossover analysis of satellite radar altimetry', Annals of Glaciology 20, pp. 26-32.

Linton-Smith, N. (1991) 'Alone on the Amery Ice Shelf, 1969-70', Aurora 10(3), pp. 11-14.

LiU, H. \& JEZEK, K.C. (2004) 'A complete high-resolution coastline of Antarctica extracted from orthorectified Radarsat SAR imagery', Photogrammetric Engineering \& Remote Sensing 70(5), pp. 605-16.

Manson, R., Coleman, R., Morgan, P.J. \& King, M.A. (2000) 'Ice velocities of the Lambert Glacier from static GPS observations’, Earth Planets and Space 52(11), pp. 1031-36.

MeIER, M.F. (1993) 'Ice, climate and sea level: Do we know what is happening?', in Peltier, W.R. (ed.) Ice in the climate system, Springer, Berlin, pp. 141-60.

MorGan, V.I. \& BuDD, W.F. (1975) 'Radio-echo sounding of the Lambert Glacier Basin', Journal of Glaciology 15(73), pp. 103-11.

NASA (2007a) http://landsat.gsfc.nasa.gov/ (accessed 15 October 2007).

NASA (2007b) http://icesat.gsfc.nasa.gov/ (accessed 15 October 2007).

PADMAN, L., Fricker, H.A., COlEMAN, R., HowARD, S. \& EROFEEVA, L. (2002) 'A new tide model for the Antarctic ice shelves and seas', Annals of Glaciology 34, pp. 247-54.

PHILLIPS, H.A. (1999) 'Applications of ERS satellite radar altimetry in the Lambert Glacier - Amery Ice Shelf system, East Antarctica', unpublished PhD thesis, University of Tasmania, Hobart, Australia.

Phillips, H.A., Allison, I., Coleman, R., Hyland, G., Morgan, P.J. \& Young, N.W. (1998) 'Comparison of ERS satellite radar altimeter heights with GPS-derived heights on the Amery Ice Shelf, East Antarctica', Annals of Glaciology 27, pp. 1924.

Phillips, H.A., Allison, I., Craven, M., Krebs, K. \& Morgan, P. (1996) 'Ice velocities and grounding line location in the Lambert - Amery system, East Antarctica', pres. at Western Pacific AGU Meeting, 23-27 July, Brisbane, Australia.

RAUP, B.H., SCAMBOS, T.A. \& HARAN, T. (2005) 'Topography of streaklines on an Antarctic ice shelf from photoclinometry applied to a single advanced land imager (ALI) image', IEEE Transactions on Geoscience and Remote Sensing 43(4), pp. 73642. 
Ridley, J.K., LAXON, S., RAPley, C.G. \& MANTRIPP, D. (1993) 'Antarctic ice sheet topography mapped with the ERS-1 radar altimeter', International Journal of Remote Sensing 14(9), pp. 1649-50.

RignOT, E. (2002) 'Mass balance of East Antarctic glaciers and ice shelves from satellite data’, Annals of Glaciology 34, pp. 217-27.

Rosen, P.A., Hensley, S., Joughin, I.R., Li, F.K., Madsen, S.N., Rodriguez, E. \& Goldstein, R.M. (2000) 'Synthetic aperture radar interferometry', Proceedings of the IEEE 88(3), pp. 333-82.

Shuman, C.A., Zwally, H.J., Schutz, B.E., Brenner, A.C., DiMarzio, J.P., SuchDEO, V.P. \& FRICKER, H.A. (2006) 'ICESat Antarctic elevation data: Preliminary precision and accuracy assessment', Geophysical Research Letters 33(7), L07501, DOI:10.1029/2005 GL025227.

SwithinBanK, C. (1988) 'Antarctica', in Williams, R.S.J. \& Ferrigno, J.G. (eds) Satellite image atlas of glaciers of the world, U.S. Geological Survey, Washington.

Thomas, R.H. (1979) 'Ice shelves: A review', Journal of Glaciology 24(90), pp. 27386.

VELICOGNA, I. \& WAHR, J. (2006) 'Measurements of time-variable gravity show mass loss in Antarctica', Science 311, pp. 1754-56.

Williams, M.J.M., WARNER, R.C. \& BudD, W.F. (2002) 'Sensitivity of the Amery Ice Shelf, Antarctica, to changes in the climate of the Southern Ocean', Journal of Climate 15, pp. 2740-57.

Wingham D.J., Francis, C.R., Baker, S., Bouzinac, C., Cullen, R., De ChateauThierry, P., Laxon, S.W., Mallow, U., Mavrocordatos, C., Phalippou, L., Ratier, G., Rey, L., Rostan, F., Viau, P. \& Wallis, D. (2006) 'CryoSat: A Mission to determine the fluctuations in Earth's land and marine ice fields', Advances in Space Research 37(4), pp. 841-71.

YounG, N.W. \& HyLAND, G. (2002) 'Velocity and strain rates derived from InSAR analysis over the Amery Ice Shelf, East Antarctica', Annals of Glaciology 34, pp. 228-34.

Zwally, H.J., Stephenson, S.N., Bindschadler, R.A. \& Thomas, R.H. (1987) 'Antarctic ice-shelf boundaries and elevations from satellite radar altimetry', Annals of Glaciology 9, pp. 229-35.

Author Posting. (C) Geographical Society of New South Wales Inc., 2008.

This is the author's version of the work. It is posted here by permission of the Geographical Society of New South Wales Inc. for personal use, not for redistribution.

The definitive version was published in Australian Geographer, Volume 39 Issue 4, December 2008, pp. 389-408. doi:10.1080/00049180802419245 (http://dx.doi.org/10.1080/00049180802419245) 